Nig. J. Biotech. Vol. 33 (2017) 89-96

ISSN: 01891731

Available online at

http://www.ajol.info/index.php/njb/index

and www.biotechsocietynigeria.org

DOI: https://dx.doi.org/10.4314/v33i1.13

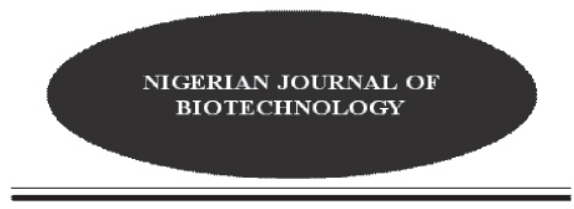

\title{
An evaluation of the phytotoxicity of municipal solid waste during co-composting with different animal manures
}

\author{
Obuotor, T.M. ${ }^{1}$ and Odeyemi, O. $^{2}$
}

${ }^{1}$ Department of Microbiology, Federal University of Agriculture, Abeokuta, Ogun State, Nigeria

${ }^{2}$ Department of Microbiology, Obafemi Awolowo University, Ile-Ife, Osun State, Nigeria

(Received: 09:06:2017; Accepted:10 :07:2017)

\begin{tabular}{|} 
Copyright resides with the authors in terms of the Creative Commons License 4.0. \\
See http://creativecommons.org/licenses/by/4.0/ \\
Condition of use: The user may copy, distribute, transmit and adapt the work, but must recognize the \\
authors and the Nigerian Journal of Biotechnology
\end{tabular}

\section{Abstract}

Composting is a bioxidative process carried out under controlled conditions which utilizes naturally occurring microorganisms for organic waste recycling. In this study, a 60 days cocomposting experiment of different treatment consisting of municipal solid wastes and plant wastes with cow dung, poultry dropping and swine manure were investigated.Compost maturity parameters and phytotoxicity, during co-composting of municipal solid waste (MSW) with different animal manures (3:1 w/w) were evaluated. Four composting treatment set-ups: MSW (control), MSW+Swine Manure (SM), MSW+Poultry Manure (PM) and MSW+Cattle Manure (CM) were prepared and composting carried out for 60 days. Changes in temperature and pH were measured daily while Electrical Conductivity, Organic Matter, Total Organic Carbon, Total Kjedahl Nitrogen, and carbon/nitrogen ratios were assessed at day 0 and day 60 . Humification process and phytotoxicity of the treatments were assessed at days $0,10,20,30,40,50$ and 60, using maize seeds germination bioassays. MSW+PM treatment showed the highest temperature of $63^{\circ} \mathrm{C}$ during the thermophilic phase while the control showed the least. The pH at the end of composting in all treatments exhibited alkaline values with MSW+CM showing the highest value of 8.6. Maturity indices showed that there were significant decreases in organic matter, $\mathrm{C} / \mathrm{N}$ and $\mathrm{NH}_{4}+-\mathrm{N} / \mathrm{NO}_{3}--\mathrm{N}$ ratios in all the treatments when compared with the control. At the end of composting, Germination index( GI) values varied from 52.56 to $97.23 \%$ with MSW+PM showing the highest germination index (GI?) of $97.23 \pm 6.08 \%$ followed by MSW+CM and MSW+SM with GI values of $88.4 \pm 6.3$ and $84.8 \pm 5.3 \%$ respectively. The germination index indicated that there were significant reductions in the phytotoxicity of the treatments.

Keywords: Composting, municipal solid waste, phytotoxicity, poultry manure, seed germination test

Correspondence: tolumikoya@yahoo.com

\section{Introduction}

Global concerns on the environment in recent times have encouraged world leaders to put in place legislative and regulatory measures aimed at promoting sustainable development in many countries worldwide. One key feature of these measures has been the greater emphasis on reducing waste volume through recycling as well as a move away from solid waste landfilling (CunhaQueda, 2007; Xiao et al., 2009). Solid waste management through effective disposal methods has become a considerable issue albeit a challenging task to the relevant government agencies especially for densely populated cities in many developing countries.

In Nigeria, the volume of municipal waste and bio solids has ever been increasing, particularly in the major cities and towns, owing ostensibly to increase in population and by extension anthropogenic activities (Ogunwande et al., 2008). Presently, the main municipal solid waste (MSW) disposal method is through unsanitary landfilling and incineration at open dump sites. This practise produces much of secondary pollutants, such as landfill leachate, greenhouse gases and odour.

$$
\text { Presumably, owing to the enormous }
$$


investment, long processing cycle and unstable products in a conventional composting treatment, only a few MSW are treated by composting in Nigeria. composting, whose chief aim is to convert organic waste into a relatively stable material reduces the volume and stabilizes the waste to obtain a final product that is stable, free of pathogens and without phytotoxicity to plants (Choy et al., 2015; Selim, 2012; Nas and Bayram, 2008). Consequently, a composting process must be suitably managed and the progressive changes carefully controlled to give an end-product with optimum qualities which is often characterised in terms of its maturation and stability (Vergnoux et al., 2008).

In the evaluation of compost quality, a number of physico-chemical parameters such as $\mathrm{pH}$, electrical conductivity, carbon form, inorganic nitrogen forms and cation exchange capacity and biological parameters such as germination index have been used successfully as indicators of compost stability and maturity of different compost mixes. In this regard, one of the most widely accepted parameter is the seed germination test which is also a measure of the phytotoxicity (CunhaQueda et al., 2007).

Thus the purpose of this investigation is to comparatively evaluate some maturity indexes and phytotoxicity of municipal solid waste cocomposted with different manures in a rotary drum (composter) under 60 days, using the germination tests of maize seeds (Zea mays).

\section{Materials and methods}

\section{Composting and sampling}

The municipal solid waste (MSW) was collected from dump site in Ile-Ife, Osun state, Nigeria. It was source selected before use. Fresh cow dung was obtained from the Adesanmi abattoir, Ede road, Ile-Ife while the poultry manure and swine manure were obtained from the respective animal units at the Teaching and Research Farm of the Obafemi Awolowo University. The experimental set- ups were made up of four composting treatment mixes consisting of thirty kilograms (30 $\mathrm{kg}$ ) each of a mixture of the MSW and animal manures (3:1, w/w) as follows: (i) MSW (Control) (ii) MSW + Poultry Manure (PM) (iii) MSW + cattle manure (CM) and MSW + Swine manure (SM). Composting was carried out in a perforated rotary drum composter $(\mathrm{H}=0.35 \mathrm{~m}, \mathrm{D}$ $=0.30 \mathrm{~m})$ for 60 days and the drums were rotated once every 3 days. Moisture content was maintained to $60-65 \%$ during composting. Triplicate compost samples were collected from the rotary drum, air-dried, ground to below $0.25 \mathrm{~mm}$ and subjected to analysis.

\section{Physico-chemical analysis}

The moisture and organic matter (OM) contents of the samples were determined after drying at $105^{\circ} \mathrm{C}$ for $24 \mathrm{~h}$ and ashing at $55^{\circ} \mathrm{C}$ for $4 \mathrm{~h}$ respectively (Curtin et al., 2012). The $\mathrm{pH}$ and electrical conductivity (EC) were determined in aqueous extracts $(1: 10)$ using a Hanna Digital Combo Meter (H1991405, Hanna, UK). The $\mathrm{NO}_{3}--\mathrm{N}$ and $\mathrm{NH}_{4}+-\mathrm{N}$ were determined in $0.5 \mathrm{M}$ K2SO4 extracts (1: $10, \mathrm{w} / \mathrm{v}$ ) by the modified indophenol blue technique (Barrena et al., 2014), with a microplate reader (Bio-Rad Model 550). Total N (TKN) was by semi-micro Kjeldahl analysis. Available phosphorus was determined in extracts of $0.5 \mathrm{M} \mathrm{NaHCO}_{3}$ (1:100) followed by analysis with the molybdate-ascorbate method while the total organic carbon (TOC) was determined according to the colorimetry method as described (Gabhane et al.,2012). The C/N ratio was computed from contents of Total Organic Carbon (TOC) and total nitrogen in dried samples. The humic acid and fulvic acid concentrations were determined on the test sample extracts using $0.1 \mathrm{M} \mathrm{Na}_{4} \mathrm{P}_{2} \mathrm{O}_{7}+\mathrm{NaOH}$ extraction and precipitation at $\mathrm{pH} 2$ followed by spectrophotometric measurement at 465 and $665 \mathrm{~nm}$ respectively (Huang et al., 2015).

\section{Germination test}

The seed germination tests were performed with maize seeds (Zea mays) according to the method described by Selim et al.,, 2012. The test were carried out on the $10 \%$ crude aqueous extracts of the compost sample. A quantity $(0.5 \mathrm{ml})$ of each extract was pipetted into a sterilized plastic petri dish lined with a Whatman No 2 filter paper. Ten maize seeds were then evenly placed on the filter paper and incubated at $25^{\circ} \mathrm{C}$ in the dark for 72 hrs after which treatments were evaluated by counting the number of germinated seeds and measuring the length of roots. Three replicates for each sample of the compost. The germination index (GI) was computed using the following formula: $\mathrm{G} . \mathrm{I}=(\mathrm{Gt} \times \mathrm{Lt}) /(\mathrm{Gc} \times \mathrm{Lc}) \times 100$ Where: $\mathrm{Gt}=\%$ of seed germination in test sample

$\mathrm{Gc}=\%$ of seed germination in control

$\mathrm{Lt}=$ root length in test sample

$$
\mathrm{LC}=\text { root length in control }
$$

(Tiqua , 2010; Selim et al., 2012)

\section{Statistical analysis}

Data are expressed as means \pm Standard error of the mean (SEM) of three independent sample replicates. One way analysis of variance (ANOVA) was performed to compare the means of treatment set-ups. Difference between means were statistically analysed using a software package, GraphPad $\AA$ Instat (version 1.4). The least significant difference test at $p=0.05$ was 
carried out to compare means.

\section{Results and Discussion}

The four composting treatment set- ups achieved thermophilic temperatures $\left(>45^{\circ} \mathrm{C}\right)$ after 10 days (Fig. 1). These temperatures were maintained for 15-25 days, and gradually declined to ambient values thereafter. The thermophilic phase lasted for 10 days longer in MSW control than in the other treatment set ups. The duration of high temperatures is consistent with results from similar studies, and has been reported to reflect the usually high proportion of degradable substances that are found in this type of waste (Tognetti et al., 2008, Curtin et al., 2012 and Sundberg et al., 2013). Though these temperatures do not correspond to optimum biological activity (around $40^{\circ} \mathrm{C}$ ), some other studies however have reported composting temperatures as high as $60-70^{\circ} \mathrm{C}$ during municipal organic waste composting which has been attributed to a consequence of heat accumulation in the treatment piles rather than corresponding to optimum biological activity of the microorganisms
(Ko et al,.2008). It has been reported that an excessive duration of thermophilic phase (beyond 6 weeks) as observed in the MSW (control) treatment may indicate an abnormally extended decomposition and a delayed transition to the stabilization stage (Satisha and Devarajan, 2007).

The $\mathrm{pH}$ values observed were in the range between 6.3 and 8.6 (Fig. 2). The lowest $\mathrm{pH}$ values (6.3) at the start of composting was observed in the MSW + SM treatment while the highest 8.6 was observed in MSW + PM. No consistent $\mathrm{pH}$ trend was observed for all the treatment set ups throughout the duration of the composting experiment, however, the $\mathrm{pH}$ values in all treatments increased to the alkaline range at the end of composting with $\mathrm{MSW}+\mathrm{PM}$ showing the highest of 8.3. Electrical conductivity (EC), values which varied between 1.53 and $2.16 \mathrm{dS} / \mathrm{m}$ (Table 1), increased in all treatments from day 0 to day 60 (Fig. 3). The values of $\mathrm{pH}$ and $\mathrm{EC}$ achieved at 60 days of composting were within the range acceptable for plant growth as recommended by Said-Pullicino et al., 2007 and similar to other values reported for Municipal organic waste (MOW) composts ( Tognetti et al., 2008).

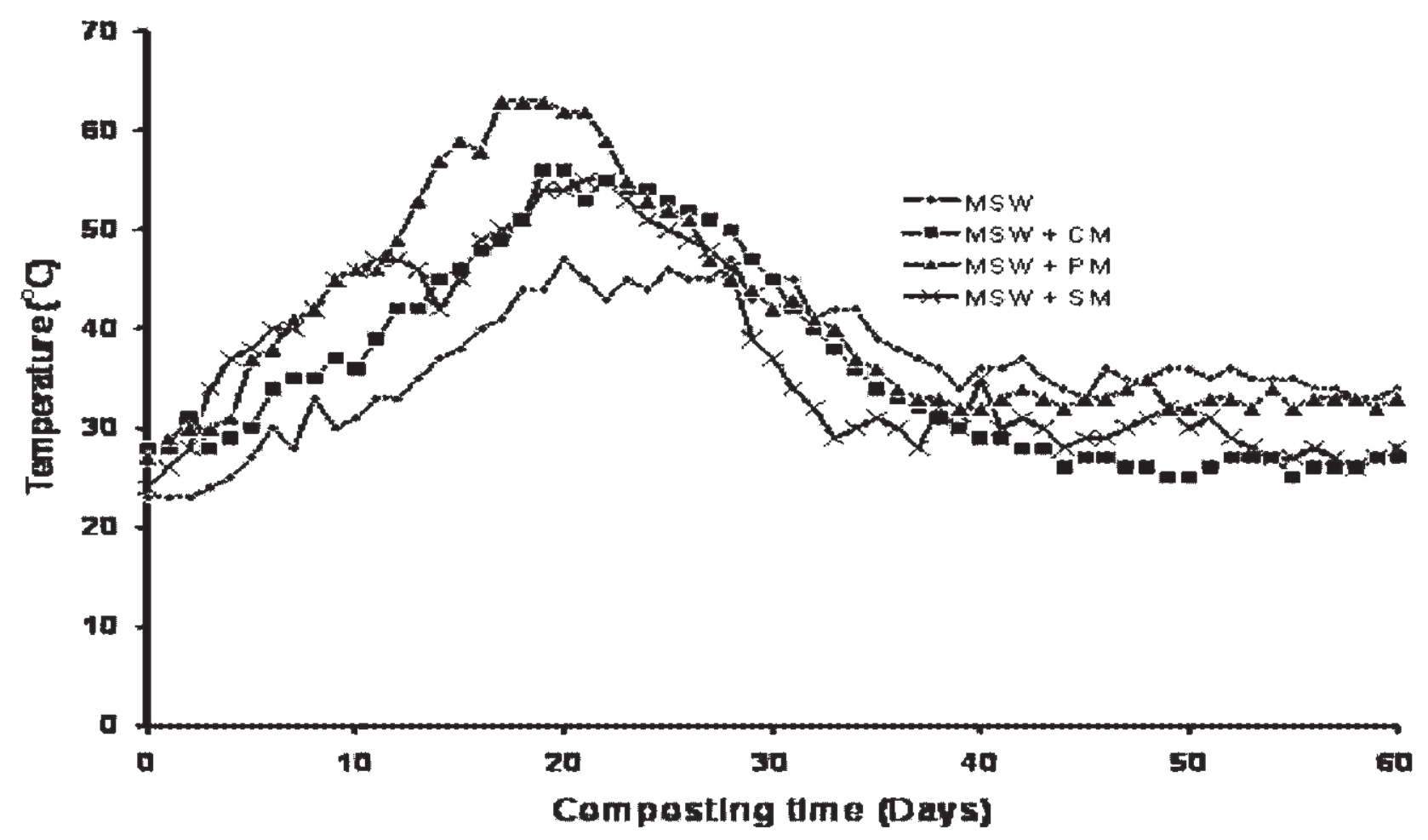

Figure 1: Changes in temperature during the composting of municipal solid waste with different animal manure Values represent mean $\pm S E M, n=3$ 


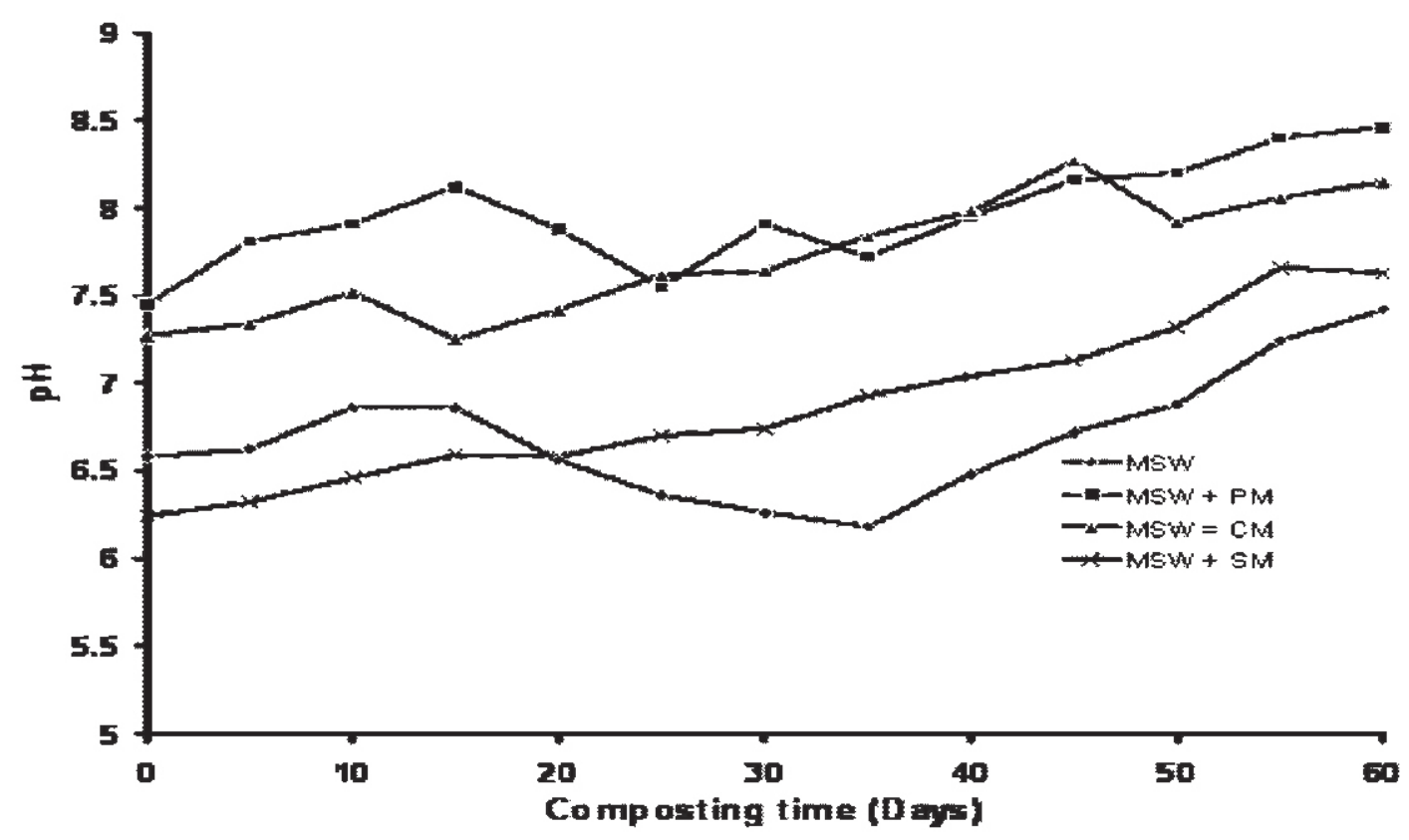

Figure 2: Changes in pH during the composting of municipal solid waste with different manures. Values represent mean $\pm \mathrm{SEM}, \mathrm{n}=3$

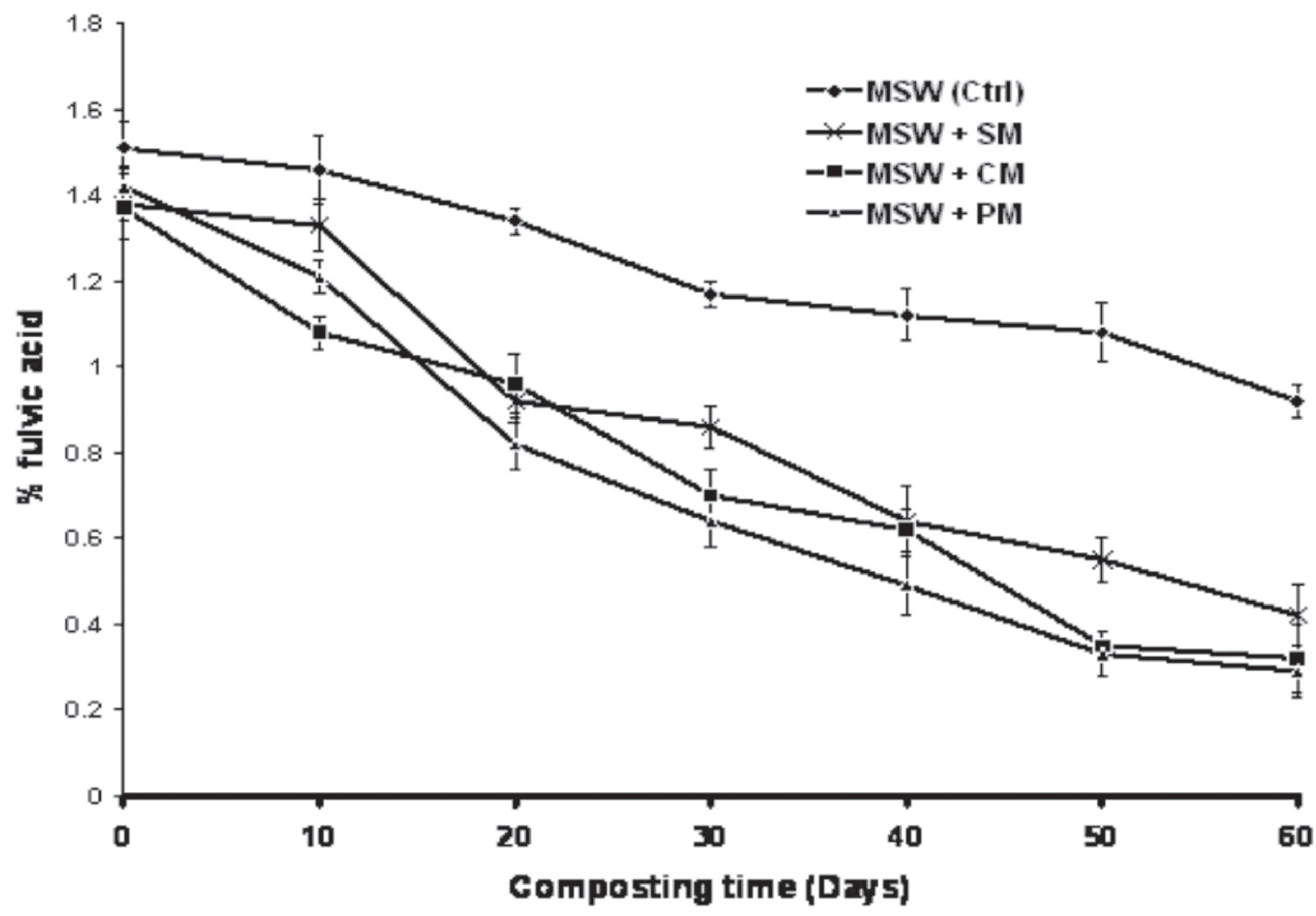

Figure 3: Changes in \% fulvic acid during the composting of municipal solid waste with different manures.

Values represent mean \pm SEM, $n=3, *$ significantly different from MSW $(C t r l),(p<0.05)$ 
Table 1. Physicochemical parameters at the initial and final stages composting of municipal solid waste with different animal manures

\begin{tabular}{|c|c|c|c|c|c|c|c|c|}
\hline \multirow[t]{2}{*}{ PARAMETERS } & \multicolumn{2}{|c|}{ MSW } & \multicolumn{2}{|c|}{ MSW + CM } & \multicolumn{2}{|c|}{ MSW + SM } & \multicolumn{2}{|c|}{ MSW + PM } \\
\hline & Initial & Final & Initial & Final & Initial & Final & Initial & Final \\
\hline$E C\left(d S m^{-1}\right)$ & $1.14 \pm$ & $1.53 \pm 0.08 \dagger$ & $1.26 \pm 0.08$ & $1.97 \pm 0.11 \dagger$ & $1.3 \pm 0.12$ & $1.88 \pm 0.10 \dagger$ & $1.35 \pm 0.07$ & $2.16 \pm 0.12 \dagger$ \\
\hline MOISTURE (\%) & $15.1 \pm 3.5$ & $34.7 \pm 4.7$ & $35.8 \pm 2.7$ & $40.2 \pm 4.2$ & $34.7 \pm$ & $41.6 \pm 2.5$ & $66.4 \pm 5.4$ & $73.6 \pm 6.3$ \\
\hline ASH & $53.5 \pm 4.8$ & $60.4 \pm 5.5$ & $53.6 \pm 3.7$ & $71.1 \pm 3.2$ & $42.8 \pm 5.2$ & $79.2 \pm 7.1$ & $56.2 \pm 6.2$ & $73.6 \pm 6.2$ \\
\hline OM (\%) & $87.2 \pm 2.8$ & $54.6 \pm 1.7$ & $76.4 \pm 3.2$ & $46.8 \pm 2.5$ & $82.6 \pm 3.8$ & $48.1 \pm 2.6$ & $83.9 \pm 4.7$ & $44.7 \pm 3.1$ \\
\hline 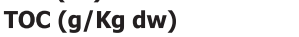 & 419. $5 \pm 13.6$ & $226.5 \pm 14.3$ & $357.6 \pm 23.2$ & $195.7 \pm 7.2 \dagger$ & $345.7 \pm 15.9$ & $206.8 \pm 14.1 \dagger$ & $388.6 \pm 25.4$ & $204.2 \pm 16.3 \dagger$ \\
\hline TKN $(g / K g d w)$ & $9.2 \pm 2.5$ & $20.4 \pm 1.3$ & $23.4 \pm 2.5$ & $30.7 \pm 4.2$ & $24.1 \pm 2.5$ & $34.2 \pm 3.6$ & $27.3 \pm 4.2$ & $34.8 \pm 3.6$ \\
\hline $\mathrm{C} / \mathrm{N}$ & $31.2 \pm 6.5$ & $25.54 \pm 3.6$ & $26.7 \pm 2.5$ & $17.6 \pm 3.3+*$ & $31.3 \pm 2.8$ & $19.4 \pm 1.7 \dagger *$ & $28.8 \pm 2.1$ & $15.7 \pm 2.11^{*}$ \\
\hline $\mathrm{NO}_{3}^{-}-\mathrm{N}(\mathrm{mg} / \mathrm{Kg} \mathrm{dw})$ & $26.8 \pm 4.6$ & $105.4 \pm 8.5$ & $78.6 \pm 7.3$ & $134.5 \pm 16.4$ & $56.8 \pm 10.2$ & $176.5 \pm 23.8$ & $45.4 \pm 5.8$ & $184.5 \pm 14.2$ \\
\hline $\mathrm{NH}_{4}+/ \mathrm{NO}_{3}^{-}$ & 15.3 & 3.1 & 6.8 & 1.8 & 8.2 & 1.1 & 8.7 & 1.2 \\
\hline Phosphorus (mg/Kg dw) & $312.1 \pm 12.3$ & $176.8 \pm 31.8$ & $267.5 \pm 12.1$ & $3227 \pm 10.6+*$ & $159.6 \pm 17.5$ & $245.7 \pm 18.3+*$ & $201.3 \pm 24.2$ & $389.7 \pm 23.8+*$ \\
\hline
\end{tabular}

Each data represent mean $\pm \mathrm{SEM}, \mathrm{n}=3, *$ significantly different from final MSW (Ctrl), + significantly different from initial value. $(p<0.05)$

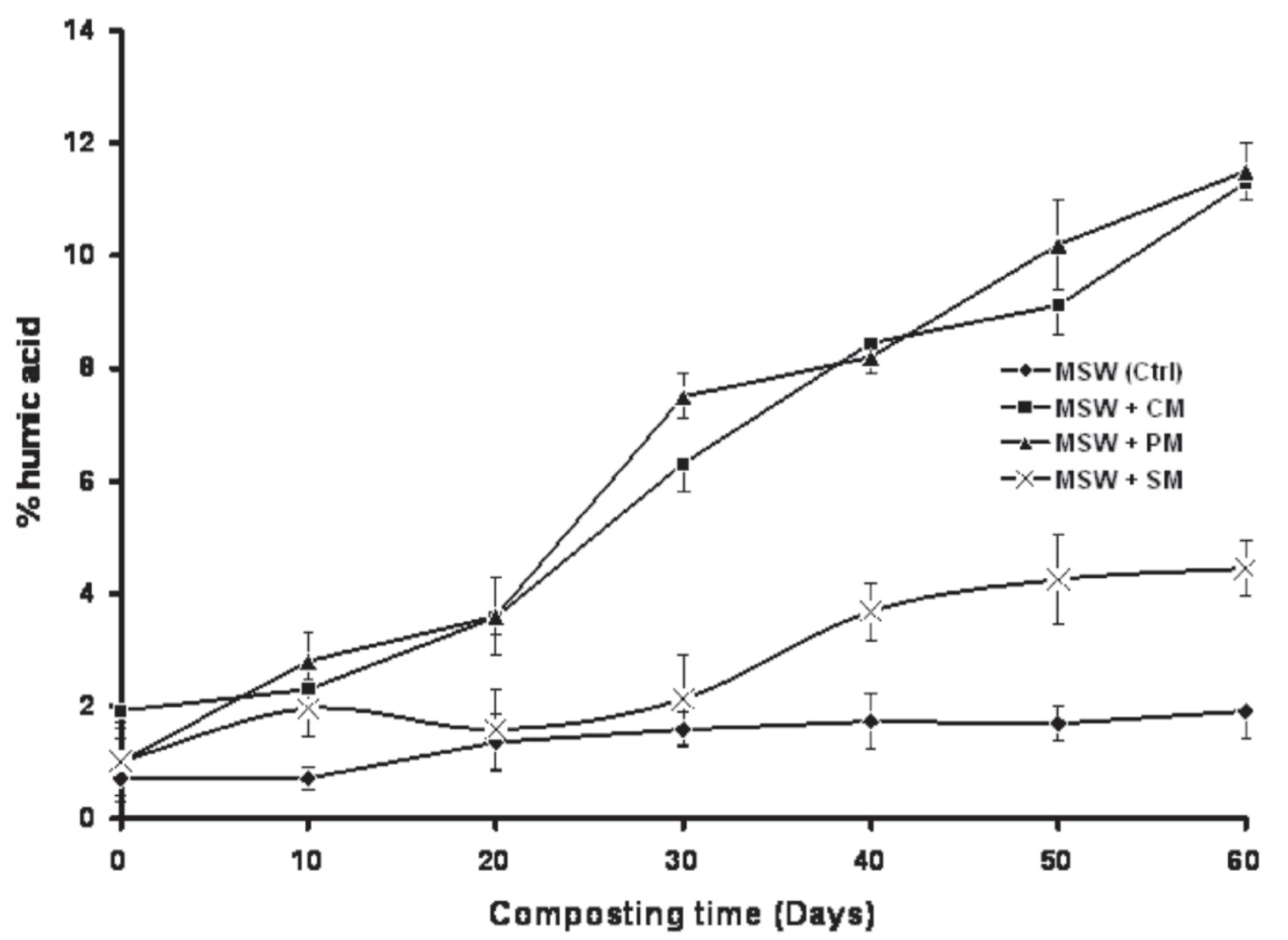

Figure 4. Changes in \% humic acid during the composting of municipal solid waste with different animal manures

Values represent mean $\pm S E M, n=3$, * significantly different from MSW $(C t r l),(p<0.05)$ 


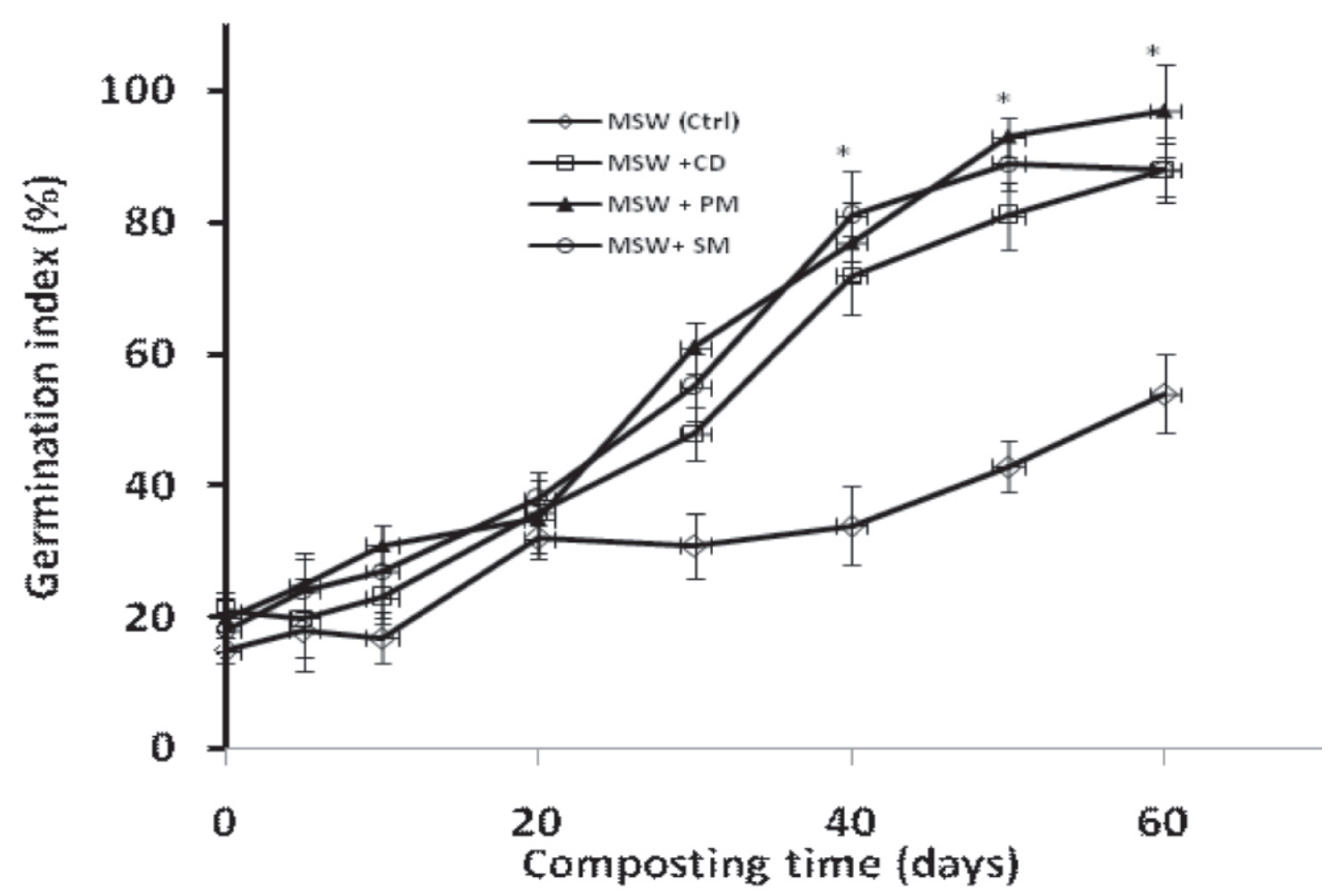

Figure 5: Changes in germination index during the composting of municipal solid waste with different animal manures

Values represent mean $\pm S E M, n=3, *$ significantly different from MSW $(C \operatorname{ctr}),(p<0.05)$

Other studies have attributed alkaline values of municipal organic waste composts to the presence of wood ashes in the wastes (Tognetti et al., 2008), which could be a common occurrence in the area from where the MSW samples used in this study was obtained, being a semi urban city. Kong, D. et al., (2012) had earlier noted that the change of mesophilic to thermophilic conditions during municipal waste composting coincided with a change in $\mathrm{pH}$ from acidic $(<6)$ to alkaline $(8-9)$. These alkaline values were attributed to proton consumption during decomposition of volatile fatty acids, which is usually abundant in the initial mesophilic phase, during which organic- $\mathrm{N}$ mineralization to $\mathrm{NH}_{4}+-\mathrm{N}$ occurs as a result of intensive proteolysis during protein degradation (Satisha and Devarajan, 2007).

In the present study, MSW + PM had the highest $\mathrm{pH}$ values, possibly due to intensive thermophilic phase, which could have favoured extensive organic- $\mathrm{N}$ ammonification when compared to the other treatment set-ups. On the other hand there were no significant differences between the final EC values of the different compost treatments, however, EC value increased significantly $(p<0.05)$ between initial values and final values in all the treatment set-ups including the control (Table 1). A sharp increase in EC values due to the release of soluble salts like ammonium and phosphate after the degradation of the most labile compounds in the thermophilic stage of composting has been reported by several investigators (Tiquia 2010). It is well established, that EC reflects the salinity of an organic amendment and that high salt concentration has been reported to cause phytotoxicity problems and therefore EC is a good indicator of the suitability and safety of compost for agricultural purposes (Tiquia 2010). Since none of the treatment set- up had EC value exceeding the threshold value of $4 \mathrm{dS} \mathrm{m}^{-1}$ it may indicate that the compost samples can be safely applied to soil (Ko et al ., 2010).

With respect to the maturity and stability parameters measured, the results showed that at the end of the composting period most of the observed values had attained thresholds as recommended by different investigators (Table1). For instance, in all the treatments except for the MSW (Ctrl) the OM $<10$ $\mathrm{mg} / \mathrm{kg}, \mathrm{C} / \mathrm{N}<20, \mathrm{NH}_{4}+-\mathrm{N}<400 \mathrm{mg} / \mathrm{kg}, \mathrm{NO}_{3}{ }^{-}-\mathrm{N}>$ $160 \mathrm{mg} / \mathrm{Kg} \quad \mathrm{NH}_{4}+-\mathrm{N} / \mathrm{NO}_{3}-<68 \mathrm{mg} / \mathrm{Kg}$ (Bernal et al., 2009, Raut et al.,2008; Choy, 2015.) High rates of OM degradation, and substrate transformation are characteristic of active composting (Saaglia et al., 2011). Decreases of $O M$ and $C / N$ during the 
composting process have been widely reported (Barenna et al., 2008; Antil, 2014)., to be indicative of active mineralization of $\mathrm{OM}$ by microorganisms. This observation apparently indicates all the three manures stock are suitable for composting of municipal organic waste and that maturity of compost could be achieved within a 60 days period when carried out under controlled composting conditions as employed in this study such as the use of a rotary drum.

As shown in Fig. 4, the concentration of humic acid as a percentage of humic substance increased gradually over the first 20 days and then increased sharply from 25 to 60 days in all the treatment groups except in MSW (ctrl). MSW + PM and MSW + CM showed quite a remarkable and significant $(p<0.05)$ increases compared to MSW + SM . By contrast, the concentration of fulvic acid (FA) decreased steadily in all the treatment set-ups during the composting process. This observation is consistent with that obtained in other similar investigations which related increased level of $\mathrm{HA}$ or decrease in FA with the occurrence of humification process. Several studies have used humification parameters as index for compost maturity (Antil, 2014). He also reported that the CHA/CFA ratio greater 1.6 is indicative of compost maturity.

Selim et al., (2012) using a combination of gel chromatography, $E_{4} / E_{6}$ ratio, FTIR and fluorescence spectroscopy reported the formation of polycondensed higher molecular weight compounds through aromatization to account for the increases in $\mathrm{HA}$ as an indicator of humification and maturity in the co-composting of pig manure and sawdust.

Fig. 5 shows the changes in GI of the different treatment set -ups during 60 days of composting. The GI increased gradually in all treatment set ups during first 30 days of composting indicating that the elimination of phytotoxicity was slow. However, from day 21 onwards, the GI in all the treatment set up increased sharply and were significantly different when compared to the MSW (Ctrl) from day 40 . The germination index which is a relative seed germination ratio to that of root growth is an indicator of phytotoxicity and one of the veritable index in assessing compost maturity and stability (Selim et al., 2012). It is generally considered that phytotoxicity is eliminated when GI attains a level greater than $80 \%$ (Tiquia, 2010). In this maize seeds germination was inhibited by to a greater degree in the control set-up ie MSW control relative to the set ups. Generally germination index of values below $50 \%$ suggest that that phytotoxic compounds might have been fully metabolised thus inhibiting germination (Selim et al., 2012). In case of MSW control the salt concentration might have inhibited the maize development.

\section{Conclusion}

It can be inferred from this study that the maturity parameters and germination index of the different compost indicates that though all the three animal manures could be used as suitable activators for the composting of municipal solid waste, poultry manure had the best activating properties amongst the three manures under the experimental conditions used in this study. These observations could be relevant for the improvement of municipal solid waste management in many developing economies. Furthermore the low technical and economical requirements of the modified Rapid Berkly method as used in this study could make it a promising option in unban localities.

\section{References}

Antil, R.S., Raj, D., Abdalla, N., Inubushi, K. (2014). Physical, Chemical and Biological parameters for compost maturity assessment: A review. In: Maheshwari, D. (eds) Composting for sustainable development and biodiversity 3, pp 83-101

Barrena, R., Font,X., Gabarrelle, X., Sanchez, A. (2014). Home composting versus industrial composting : Influence of composting system on compost quality with focus on compost stability. Waste Management 34 (7): $1109-1116$

Bernal, M.P., Alburquerque, J.A. and Moral R. (2009). Composting of animal manures and chemical criteria for compost maturity assessment. A review. Biores. Techn. $100(22): 5444-5453$

Choy, S.Y., Wang, K, Q.W., Wang B., Chen, C. and Wang, J. (2015). Co composting of horticultural wastes with fruit peels, food waste and soybean residues. Environ. Techn. 36 (11) : 1448-1456

Cunha-Queda, A.C., Ribeiro, H.M.., Ramos, A. and Cabral, F. (2007) Study of biochemical and microbiological parameters during composting of pine and eucalyptus bark. Biores. Techn. 98: 3213-3220.

Fialho, L.L., Lopez da Silva, W.T., Milori, D.M.B., Simoes, M.L., Martin-Neto, L. (2010). Characterization of organic matter from composting of different residues by physicochemical and spectroscopic methods. Biores. Techn. 101(6) : 1927-1934

Gabhane, J., Williams S.P.M.P, Bidyadhar,P. Bhilawe, P., Anad, D., Vaidya, A.N and Wate, S.R. (2012). Addictives aided composting of green wastes: Effects on organic matter decomposition, compost maturity and quality of 
finished compost. Biores. Techn. 114: 382-388

Huang, H., Zeng, G.,Luo,L., Zhang, J., Yu,M. and Qin,P (2015). Effect of inoculation during different phases of agricultural waste composting or spectroscopic characteristics of humic acid. J. Central South Univ. 22 (11): 4177-4183

Khan N.,Clark I., Sanchez-Mondero, M.A, Shea S., Meier S., Bolan N. (2014). Maturity indices in co composting of chicken manure and sawdust with biochar. Biores. Techn. 168, 245-251

Kong,D., Shan, J., Lacoboni, M. And Maguin S.R (2012). Evaluating greenhouse gas impacts of organic waste management options using life cycle assessment. Waste Manage. Res. 30(8) 800-812.

Kutsanedzie F., Rockson G.N.K., Achio,S (2012). Comparison of compost maturity, microbial survival and health hazards in two composting systems. J. Microbiol. Biotechnol. Fd. Sci. 2:175-93

Nas,S.S.,and Bayram, A.(2008).Municipal solid waste characteristics and management in Gumushane, Turkey. Waste Management 28: 2435-2442.

Ogunwande, G.A., Osunade, J.A., Adekalu, K.O.and Ogunjimi, L.A.O. (2008). Nitrogen loss in Chicken litter compost as affected by carbon to nitrogen ratio and turning frequency. Biores. Techn. 99: 7495-7503.

Raut, M.P., Williams,S.P.M.P, Bhattacharyya, J.K., Chakrabarti, T., Devotta, S. (2008). A compost maturity analysis perspective. Biores. Techn. 99 (14) : 6512-6519

Said-Pullicino,D., Erriquens, F.G. and Gigliotti, G (2007). Changes in the chemical characteristics of water extractable organic matter during composting and their influence on compost stability and maturity. Biores. Techn. 98(9): 1822-1831

Satisha, G.C. and Devarajan, L. (2007). Effects of amendments on windrow composting of sugar industry pressmud. Waste Management 27 : 10831091

Scaglia, B., Orzi, V., Artola, A., Font, X., Davoli E., Sanchez, A. and Adani, F. (2011). Odours and volatile organic compounds emitted from municipal solid wastes at different stages of decomposition and relationship with biological stability. Biores. Techn. 102 (7) : 4638-4645
Sun, X., Lu, P., Jian, T., Schuchardt T. and Li,G. (2014). Influence of bulking agents of $\mathrm{CH} 4, \mathrm{~N} 2 \mathrm{O}$ and $\mathrm{NH} 3$ emmisions during rapid composting of pig manure from Chinese Gangifen system. J. of Zhejiang University Science B. 15(4) 353-364

Sunberg,C., Yu,D., Frank-Whittle, I., Kuppie, S., Smars, S., Insam H., Romantschuk, M. and Johnsson, H. (2013). Effect of $\mathrm{pH}$ and microbial composition on odor in food waste composting. Waste Management 33(1) : 204-211

Tiqua, S.M.(2010). Reduction of compost toxicity during the process of decomposition. Chemosphere, 79: 506512

Tognetti, C., Mazzarino, M.J.and Laos,F. (2008). Compost of municipal organic waste : Effects of different management practices on degradability and nutrients release capacity. Soil Biol. Biochem. 40 (9): 2290-2296

Vergnoux, A., Guiliano, M., Le Dreau, Y., Kister,]., Dupuy, N., and Doumenq, P. (2008). Monitoring of the evolution of an industrial compost and prediction of some compost properties by NIR spectroscopy. Sci. Total Environ. 407: 2390-2403.

Xiao, Y.,Zeng, G.M.,Yang, Z.H., Shi, W.J., Huang, C., Fan, C.Z. and Xu, Z.Y. (2009). Continuous thermophilic composting (CTC) for rapid biodegradation and maturation of organic municipal solid waste. Biores. Techn. 100: 4807-4813. 